DOI: https://doi.org/10.34069/AI/2021.43.07.16

How to Cite:

Shevchuk, V., Ivanchov, P., Paryzkyi, I., Lakiichuk, Y., \& Oksin, V.. (2021). Establishment of a comprehensive system for the provision of medical services in Ukraine on market principles. Amazonia Investiga, 10(43), 158-167. https://doi.org/10.34069/AI/2021.43.07.16

\title{
Establishment of a comprehensive system for the provision of medical services in Ukraine on market principles
}

\section{Формування комплексної системи надання медичних послуг в Україні на ринкових засадах}

Received: July 7, 2021

\section{Abstract}

The aim of the article is to develop recommendations for the formation of a comprehensive system of medical services in Ukraine on a market basis. Subject of research is the formation of a model of such a medical system, which would guarantee the quality, accessibility and transparency of medical services for the population. Methodology: In the course of the research the following methods are used: analysis and synthesis methods, structural and systematic analysis method, graphic method, method of generalization. Research results: The principles of State management of the transformation of health care systems in Ukraine to support the development of the medical services market are established. The stages of State management of the medical system transformation process in accordance with market principles of functioning are described. Practical consequences: The model of the comprehensive system of providing medical services on a market basis, as well as the assurance of highly specialized and high-tech types of medical care to all the people are
Accepted: August 12, 2021

\author{
Written by: \\ Vasyl Shevchuk ${ }^{57}$ \\ https://orcid.org/0000-0002-6634-723X \\ Pavlo Ivanchov ${ }^{58}$ \\ https://orcid.org/0000-0001-6201-4203 \\ Igor Paryzkyi ${ }^{59}$ \\ https://orcid.org/0000-0001-6835-5930 \\ Yaroslava Lakiichuk ${ }^{60}$ \\ https://orcid.org/0000-0002-1482-8146 \\ Vitaliy Oksin ${ }^{61}$ \\ https://orcid.org/0000-0001-6080-7752
}

\begin{abstract}
Анотація
Метою статті є розробка рекомендацій щодо формування комплексної системи медичних послуг в Україні на ринковій основі. Предметом дослідження є формування моделі такої медичної системи, яка гарантувала б якість, доступність та прозорість медичних послуг для населення. Методологія: У ході дослідження використовуються наступні методи наукового пізнання: методи аналізу та синтезу, структурний метод, метод систематичного аналізу, графічний метод, метод узагальнення. Результати досліджень: Визначено принципи державного управління трансформацією систем охорони здоров'я в Україні для підтримки розвитку ринку медичних послуг. Описано етапи державного управління процесом трансформації медичної системи відповідно до ринкових принципів ¥іi функціонування. Практичні наслідки: Запропоновано модель комплексної системи надання медичних послуг на ринковій основі, а також гарантії забезпечення високоспеціалізованих та високотехнологічних видів медичної
\end{abstract}

\footnotetext{
${ }^{57}$ Doctor of Economics, Director General of the Center for Sustainable Development Studies, Ukraine.

58 Doctor of Medical Sciences, Head of Surgery Department №3 of O. Bohomolets National Medical University, Ukraine.

${ }^{59}$ Doctor of Economics, PhD in Law, Professor of the Department of Marketing, Economics, Management and Administration, ViceRector for Strategic Development of the Higher Educational Institution "National Academy of Management", Ukraine. ${ }^{60} \mathrm{PhD}$ in Law, Senior Research Fellow of the Academic Council of the National Academy of Internal Affairs, Ukraine.

${ }^{61}$ Doctor of Law, Leading Researcher of the Scientific Institute of Public Law, Ukraine.
} 


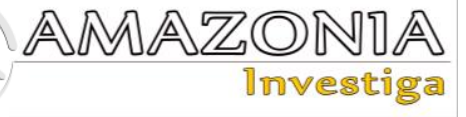

proposed. Value / originality: It is determined that the changes in the health care system should be based on prudent public administration, which, in its turn, is grounded on the relevant principles, defined by the authors.

Key words: health care, medical services, medical services market, medical system, public administration.

\section{Introduction}

Nowadays, the reform of the health care system occupies the leading place among the main priorities of the State development policy, as the health of the nation is one of the most important and significant criteria for the formation and development of human capital in the country. To this end, Ukraine has been actively taking steps to reform the medical system since 2017 , which envisages the transition from administrativecommand State medicine to a system based on market principles. However, the implemented measures are characterized by several problematic points, in particular:

- the need for sustainable State control, which, despite the delegation of authority to the local bodies and increasing the freedom of market participants in economic activities and public administration, still remains crucial in the formation of financial mechanisms and achieving social goals of the system. At the same time, it is important that public administration methods promote the development of market relations without complicating the activities of service providers with excessive regulation;

- the price of medical services (especially at the secondary and tertiary levels of care) is determined by the tariff based on the results of treatment, through which providers receive a fixed payment for procedures. However, it is necessary to take into account the contradictions of this point, because on the one hand it can help reduce costs and encourage organizations to compete for quality, not price, and on the other hand it may hinder the efficient market, because the tariff for the treated case for different suppliers may differ and not always coincide with the specified standard. In this case, more innovative institutions that invest in new technologies and equipment will bear the expenses. Therefore, to avoid "shadow" payment, it is important to optimally calculate treatment rates, focusing on operating costs (including innovative) of

допомоги населенню. Цінність / оригінальність: Визначено, що зміни в системі охорони здоров'я повинні базуватися на продуманому державному управлінні, яке, у свою чергу, грунтується на відповідних принципах, запропонованих авторами.

Ключові слова: медична система, медичні послуги, ринок медичних послуг, державне управління, охорона здоров'я.

different types of medical institutions depending on the size, material and technical base, wages, utilities, etc., as well as to attract various financial resources to pay for services;

- autonomization of health care providers makes it possible to respond to contractual requirements and changing market conditions, increasing their entrepreneurial flexibility. However, this requires medical institutions, which used to be «guided» from above, to be responsible for their activities, to develop a management system (corporate governance, risk management, strategic planning, financial management, public administration, etc.), to which many agencies are not ready;

- price competition in the market of medical services does not work, so information about medical services and quality requirements are important in the formation of competitive advantages, because most consumers (patients) are not aware of the specifics of treatment procedures and cannot reliably the level satisfaction with the latter. Quality is often assessed subjectively and depends on the speed of response to the request, the correctness of diagnosis and treatment, duration and cost of treatment, the level of service in the medical institution and moral and ethical qualities of doctors;

- the quality of medical services, which is assessed both by the level of satisfaction of patients' requirements and economic efficiency. Currently, the key to improving the quality of medical care is the introduction of innovations and results of research, which, despite the initial higher cost, guarantee competitive advantages in the market and a short payback period;

- payment for medical services and guarantee of the principle of availability of medical care, because the amount of consumption of medical services cannot be determined only by the level of remuneration, but depends on the need for them. At the same time, it is 
natural that people with lower income and well-being often have a greater need for medical care. This is contrary to the usual market laws, but is subject to the unquestionable right of people to health care, and requires government intervention and, consequently, the search for ways to finance health care;

- the consumer (patient) is not decisive in regulating the market situation and is forced to act in accordance with the rules established by the State, because receiving free medical services (compensation under the State guarantee package) is possible by a clear algorithm for seeking medical care. Otherwise, the cost of treatment will be borne by the patient.

Given the existing gaps, we consider it necessary to strengthen public administration and the transformation of the medical system, the key task of which is the formation of legal, managerial and financial mechanisms that would work based on market principles. Accordingly, the scientific substantiation of the formation of a new comprehensive model of the medical system in Ukraine determines the relevance of our study.

\section{Methodology}

The research uses the following general and special scientific research methods, in particular: theoretical methods (analysis and synthesis methods) are applied to identify the current state of development of the health care system, and highlight the problems to be solved in the State management of the medical system in terms of its reform. Structural and systematic analysis method helps to summarize the aspects that determine the current state of the issue, as well as to formulate the comprehensive model of the medical system based on market principles. Graphic method is used for visual display of structural and functional relations between the participants of the medical system and the financial mechanism of payment for medical care in the functioning of the medical services market. Method of generalization makes it possible to formulate the recommendations and the relevant conclusions of the study.

\section{Literature Review}

The issue of changing the health care system to improve the availability and quality of health care is relevant to all countries of the world and has been repeatedly raised by the World Health Organization and other international organizations. Bearing this in mind, a number of scholars (Ginter, Duncan, \& Swayne 2018; Shohet 2006; Nasiri \& Moselhi 2017). have studied the issue of improving the efficiency of the national health care system as a key component of public administration. At the same time, the foreign experience of health care reform, described in the works of foreign authors (Ling, \& Hongqiao 2017; Obama 2016; Clemens et al. 2014; Dubas-Jakóbczyka, KowalskaBobkob, Sowadaa 2019; Rechel et al. 2011), does not fully correspond to the Ukrainian realities and the existing medical system, which is currently in the process of reforming in accordance with world best practices, but nowadays operates on the basis of the state administrative-command system.

Some issues related to public administration of the health care system have been examined by Ukrainian scientists (Bilynska \& Radysh 2013; Kravchenko, \& Shpachuk 2019; Safonov, \& Borshch 2019; Tomchuk-Ponomarenko et al. 2021; Lekhan et al. 2015), but the works of scientists on the development of the medical system on the basis of market relations deserve special attention.

Some authors (Tomchuk-Ponomarenko et al. 2021; Lekhan et al. 2015) raise the issue of reforming the management of the health care system of Ukraine, emphasizing the need to address certain issues related to the legislative support of the transformation process, development of a clear reform strategy, application of the best practices in health care reform and integration of world best practices. Instead, the other scholars (Voronenko, \& Goyda 2013; Muzyka 2016) focus on the problems that arise in the process of reforming the medical system of Ukraine, primarily the lack of a clear reform strategy, inadequate legislation, corruption, lack of public financial support for the reform, etc.

The peculiarities of the reform of the health care system of Ukraine in terms of changing the funding scheme and mechanisms for attracting and using limited financial and other resources were considered in the works by (Avila 2021; Lekhan, Rudiy, \& Shishkin 2007). Besides, some authors (Betliy, Kuziakiv, \& Onishchenko 2007; Bilinskyi, \& Damirchyiev 2019; Pashkov, Udovyka, Dichko 2018) pay attention to the issue of compliance of changes in the medical system with international standards and international health law.

Nevertheless, a limited number of scientific papers are devoted to the formation of the market 


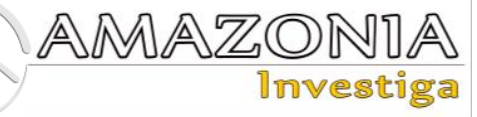

of medical services in Ukraine. Some of them (Vasyuk 2018; Barzylovych 2020) descriptively consider the structure of the national market of medical services in Ukraine from the angle of the mechanism of public administration of the health sector and the functional activities of these participants, and the others (Mikhno, Koval, \& Ternavskyi 2020; Shevchuk, et al. 2016) consider the state and problems of the medical services market in Ukraine and propose to promote the development of private medicine, which guarantees the attraction of additional financial resources and high-quality medical care, as well as to strengthen the management system of changes in the medical system.

Supporting the idea of State participation in the transformation process, in particular, in the reform of medicine, we believe that the development of public administration measures and a comprehensive model of the medical system of Ukraine need further justification.
Thus, the purpose of the article is to develop the recommendations for the formation of a comprehensive system of medical services in Ukraine on a market basis.

\section{Results and Discussion}

Studying the issues of State management of the transformation of the medical system on a market basis, we consider the identification of the principles, on which the market of medical services in Ukraine should develop, to be a priority. Among them, we propose to highlight the following: the absence of contradictions between clinical and economic aspects of efficiency; common economic interest; quantitative indicators do not guarantee quality; key element of the medical system is the primary level of medical care; mandatory planning of medical activities and the scope of medical services; fee for free choice of medical service provider (Table 1).

Table 1.

Description of the principles, on which the market of medical services in Ukraine should develop (created by the authors).

\begin{tabular}{|c|c|}
\hline Principles & Description \\
\hline $\begin{array}{l}\text { No contradiction } \\
\text { between clinical and } \\
\text { economic aspects of } \\
\text { effectiveness }\end{array}$ & $\begin{array}{l}\text { Priority is the clinical aspect of the activity, i.e. achieving the maximum possible result of } \\
\text { the treatment and diagnostic process. The economic aspect of the activity comes to the } \\
\text { fore in a situation, in which the choice of alternative medical technologies, methods and } \\
\text { levels of medical care is possible. Qualitatively provided medical care reduces the } \\
\text { possibility of complications of the disease and improves the patient's health, which } \\
\text { reduces the need for additional medical visits, expensive tests and hospitalization. That is } \\
\text { why improving the efficiency of resource use and the quality of health care is the main } \\
\text { task. }\end{array}$ \\
\hline $\begin{array}{l}\text { Common economic } \\
\text { interest }\end{array}$ & $\begin{array}{l}\text { The object of funding is not a particular hospital or clinic, but the whole set of } \\
\text { interconnected agencies involved in the provision of health care. Therefore, all } \\
\text { participants in the provision of medical care, in addition to their own interest in expanding } \\
\text { the scope of services provided and increasing income, should also be interested in the } \\
\text { effective functioning of the entire medical system. }\end{array}$ \\
\hline $\begin{array}{l}\text { Quantitative } \\
\text { indicators do not } \\
\text { guarantee quality }\end{array}$ & $\begin{array}{l}\text { The main efforts in the health care system are not aimed at increasing the range of } \\
\text { services provided, but at achieving the highest possible clinical results and public health } \\
\text { indicators per unit cost. The task is to ensure the optimal amount of services provided at } \\
\text { each level of medical care system. }\end{array}$ \\
\hline $\begin{array}{l}\text { Primary level of } \\
\text { medical care is the } \\
\text { key element of the } \\
\text { medical system }\end{array}$ & $\begin{array}{l}\text { Primary health care is the key element, as the vast majority of medical interventions are } \\
\text { addressed at this level, and a qualified and economically motivated general practitioner } \\
\text { can significantly reduce the overall cost of treating patients. Besides, it is at this level that } \\
\text { the patient's clinical route and the adherence to the principle of financing medical services } \\
\text { in accordance with the state-guaranteed package of services begins. }\end{array}$ \\
\hline $\begin{array}{l}\text { Mandatory planning } \\
\text { of medical activities } \\
\text { and the scope of } \\
\text { medical services }\end{array}$ & $\begin{array}{l}\text { Planning involves analyzing the activities of each service and identifying possible sources } \\
\text { of savings, as since patient flows are planned, rational volumes and structure of each type } \\
\text { of health care are determined. Relationships between medical organizations and medical } \\
\text { practices are also established on a planned basis. }\end{array}$ \\
\hline $\begin{array}{l}\text { Fee for free choice } \\
\text { of medical service } \\
\text { provider }\end{array}$ & $\begin{array}{l}\text { The free choice of a medical institution without consulting the family doctor and receiving } \\
\text { an electronic referral to a secondary and tertiary care institution entails full funding of } \\
\text { medical services at the expense of the patient. Therefore, it is economically more } \\
\text { profitable to act according to the algorithm established by the State or to develop } \\
\text { alternative types of medical care. }\end{array}$ \\
\hline
\end{tabular}


In general, the development of the medical system on a market basis implies the existence of different providers of medical services of various forms of ownership, including active development of the private health sector and the formation of communal medical institutions, which is associated with the decentralization reform of Ukraine. This is achieved through a number of activities: optimization, autonomy, decentralization, financing reform, licensing and certification, scientific and innovative, etc., which are implemented through regulatory, organizational, economic, financial aspects of their achievement (Fig. 1).

Regulatory support is based on legislation, programs, strategies and concepts of industry development. Establishment of the relevant legislative framework defines the framework for the activities of the participants in the medical services market and will create conditions for the development of insurance in the medical field, cooperation between the public and private sectors of medicine; the latter, by the way, is not a priority issue of the public policy nowadays (Shevchuk et al. 2021).

The organizational and economic unit of the transformation of the medical system includes public administration bodies, subjects and objects of the medical services market, insurance funds (companies), scientific institutions, etc. The institutional aspects of the management system are determined through the creation of special bodies and services.

Financial and investment support for changes in the medical system involves the use of instruments of financial and fiscal incentives for the development of medical institutions by innovative type. The leading role in the formation of areas of funding is to expand the ability to finance the medical system from the state budget, local budgets, insurance funds, private investors and other sources (Paryzkyi 2018).

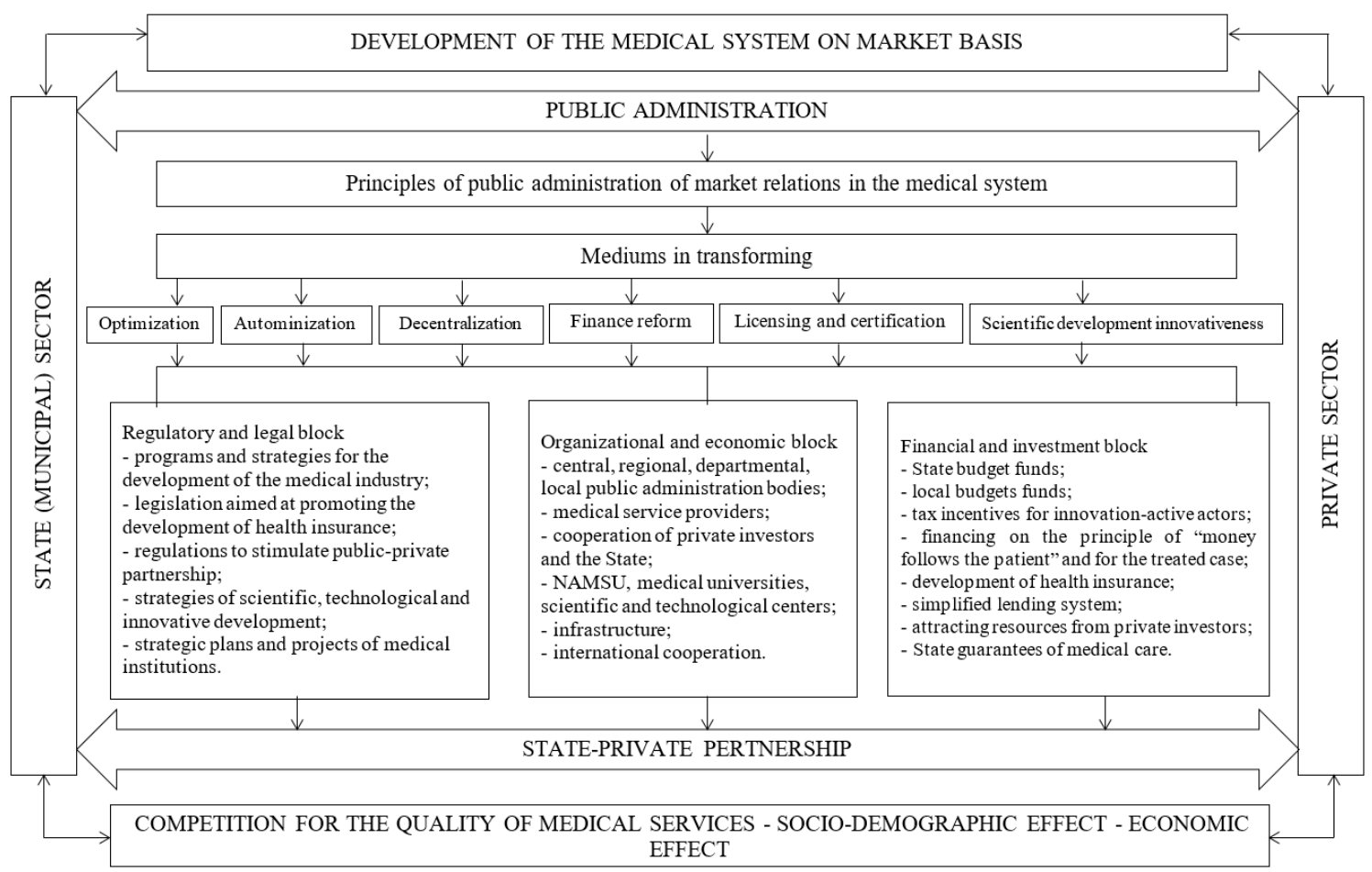

Fig. 1. Conceptual model of State management of transformation of the medical system of Ukraine on a market basis (created by the authors).

In our opinion, the practical implementation of these measures, in addition to a number of others provided for in the regulations governing the reform of the health care system in Ukraine, requires the development of health insurance, public-private partnership and the formation of innovation and technological modernization, which should be gradually implemented by means of public administration (Fig. 2). 


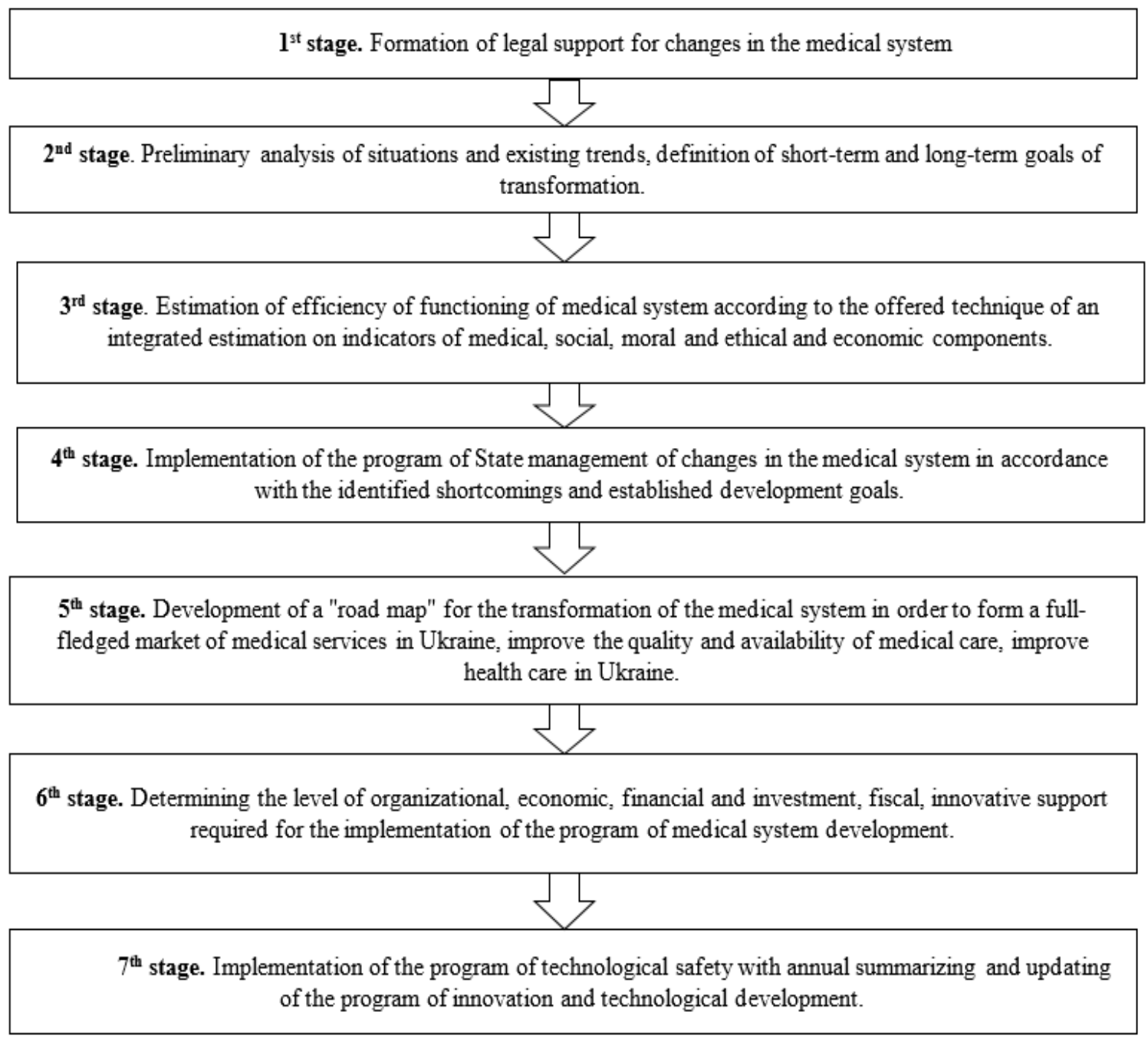

Fig. 2. Stages of public administration in the process of transformation of the medical system on a market basis (created by the authors).

Thus, the task of the current stage of development of the medical system of Ukraine is to form such a model of development of the industry and adjust it so that it can adhere to the balance of interests of the population, the State and health care institutions in the market of medical services. In accordance with the goal of transforming the medical system, which involves changing the mechanisms of financing medical institutions, patient care and the relationship between free and medical care, ensuring the availability of highly specialized and high-tech medical care to all segments of the population, the conceptual model of medical system is demonstrated in Fig. 3. 


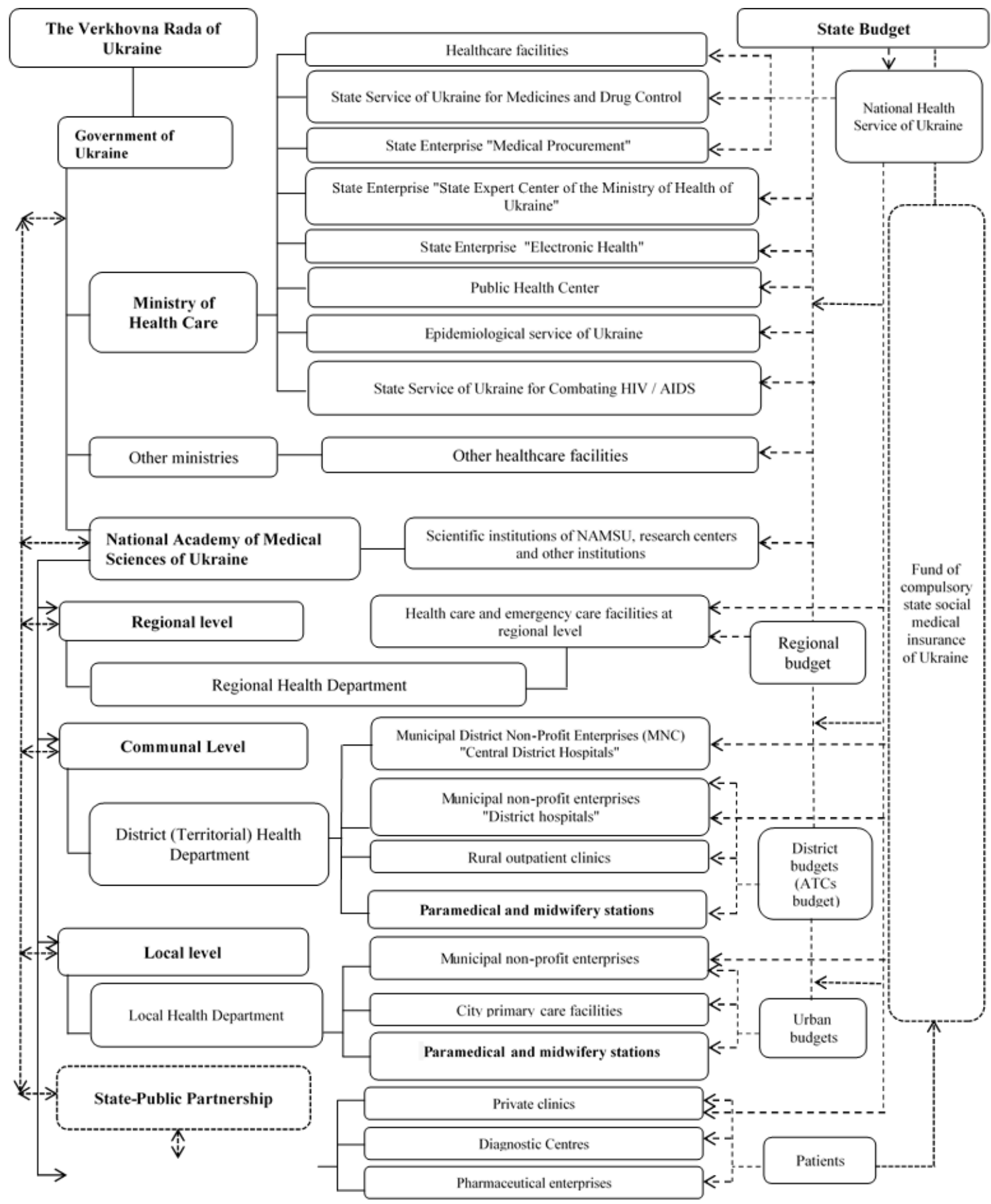

Fig. 3. Conceptual model of the medical system of Ukraine, operating on a market basis (created by the authors).

As a result, current changes in health care involve the implementation of a number of solutions and mechanisms that have been empirically tested based on the experience of other countries. However, it should be noted that the actual success of the reform activity depends on a number of additional factors such as: interest and active participation of the State and society in the market model of health care, macroeconomic stability, socio-political situation and political will to introduce new financing mechanisms and participants of medical services market in the transition to sustainable development of the country.

On September 25, 2015, the UN General Assembly (2015) unanimously defined 17 goals of sustainable development: 1) poverty eradication; 2) elimination of hunger; 3) good health and well-being; 4) quality education; 


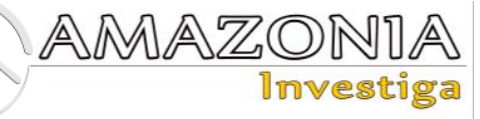

5) gender equality; 6) clean water and sanitation; 7) inexpensive and clean energy; 8) decent work and economic growth; 9) industrialization, innovation and infrastructure; 10) reduction of inequality; 11) stable cities and settlements; 12) responsible consumption and production; 13) combating climate change; 14) conservation of marine ecosystems; 15) conservation of terrestrial ecosystems; 16) peace, justice and effective institutions; 17) partnership for sustainable development.

The urgency of all 17 goals of sustainable development for Ukraine is acute and obvious.

In the post-war period of global climate change, the world must return to "green" idea. We are talking about "green" revival, "green" growth, "green" development, based on the inflow of investment in renewable energy sources, in environmentally friendly production, in "green" technologies with minimal environmental pollution. To this end, government regulation and management should support research and development of "green" technologies, the introduction of infrastructure programs, in particular, the development of public transport to reduce the negative impact of car emissions in large cities, the introduction of greenhouse gas emission limits, and preferential taxes rates for environmentally friendly production. To survive and be in good health, the world must be "green".

Bearing this in mind, we consider that the dialogue between patients, medical practitioners, government and municipal officials, academics, industry and international experts, the private sector and joint action to promote the transformation of the medical system on a market basis meets modern needs. As a result, it will help to establish clear rules for the functioning of the medical system, and their observance will allow to achieve high socio-demographic and economic health outcomes in the long term.

The transformation of the medical system, associated with the transition from an exclusively State-governed health care system to the developed market of medical services, insurance and private medicine is an urgent problem and important task of public administration for most developing countries, including Ukraine. Due to this reasons, the scientific interest for this issue among domestic scientists is constantly growing.

Despite this, the existing theoretical and empirical studies have not yet formed comprehensive recommendations for the formation of the medical system, operating on a market basis in our country. Therefore, in contrast to scientific works, which consider legal, institutional, organizational aspects of reforming the medical system, as well as analyzing the actual state of the medical industry, the article develops a comprehensive model of medical system operating on market principles, which provides for the development of State, municipal , insurance and private medicine, changes in the mechanisms of financing medical institutions, patient care and the relationship between free and paid medical care, ensuring the availability of highly specialized and high-tech types of quality medical care to all people.

Besides, in addition to the existing recommendations, which are given in the studied scientific literature, we proved that the practical implementation of these proposals requires the improvement of public administration system, including changes in legal, organizational, economic, institutional and financial and investment support of health care, focused on ensuring the activities of the providers of medical services of various forms of ownership, health insurance, etc.

Establishing the need for the development of the medical sphere in accordance with the principles of sustainable economic development, health and well-being, proclaimed by the UN as a priority for social change, is an important aspect of the study.

The practical value of the work lies in the formation of the conceptual model of the medical system of Ukraine, operating on a market basis, which ensures the balance of the interests of the population, the State and health care institutions in the market of medical services, guarantees the quality and accessibility of medical care and promotes socio-economic well-being of the country in general. Therefore, we are convinced that the provided recommendations can serve as the basis for the establishment of an adequate State policy for the development of the health care system in Ukraine.

\section{Conclusion}

Public management of the transformation of the medical system on a market basis requires a number of mutually agreed innovations, in particular the changes in the legislation, institutional environment for the management and implementation of institutions and organizations in medical sphere, the mechanism of financial support. 
It is determined that the changes in the health care system should be based on prudent public administration, which, in its turn, is grounded on the following principles: no contradiction between clinical and economic aspects of efficiency; common economic interest of all actors of the services market; quantitative and qualitative indicators of the functioning of the medical system; priority development of primary care; mandatory planning of medical activities and the scope of medical services; fee for free choice of health care provider.

As the result of the study, we formulated comprehensive model of public administration for the transformation of the medical system of Ukraine, which includes principles, tools and measures of regulatory, organizational, economic and financial-investment nature, as well as clearly defined stages of implementation of public administration measures to develop a medical system based on market principles. At the same time, the prospects for the further research are to develop detailed recommendations for promoting changes in the medical system of Ukraine in accordance with the proposed model, in particular for the development of health insurance, State-private partnership and innovation and technological modernization.

\section{References}

Avila, C. (2021). Implementing health financing policies to overhaul the healthcare delivery system in Ukraine. Journal of Hospital Management and Health Policy, Vol. 5. http://dx.doi.org/10.21037/jhmhp-20-97

Barzylovych, A.D. (2020). National medical services market participants in Ukraine. East European Scientific Journal, No. 1(53), pp. 23-28.

Betliy, O.V., Kuziakiv, O.V., \& Onishchenko, K.V. (2007). The evaluation of health care system in Ukraine in the context of structural and qualityenhancing reforms. Moscow: EERC.

Bilinskyi, D., \& Damirchyiev, M. (2019). International economic standards of medical provision: legal characteristics and problems of implementation in Ukraine. Baltic Journal of Economic Studies, 5(5), pp. 28-31. https://doi.org/10.30525/2256-0742/2019-5-528-31

Bilynska, M. and Radysh, Y., eds. (2013). State policy in health protection. Collective monograph in 2 Parts. Part 1. Kiev: NADU. http://academy.gov.ua/NMKD/library_nadu/Mo nogr/457d99ff-a477-4205-baaf-

2cee246fe3da.pdf
Clemens, T., Michelsen, K., Commers, M., Garelb, P., Dowdeswellc, B., \& Brand, H. (2014). European hospital reforms in times of crisis: aligning cost containment needs with plans for structural re-design? Health Policy, 117(1), pp. 6-14. https://doi.org/10.1016/j.healthpol.2014.03.008 Dubas-Jakóbczyka, K., Kowalska-Bobkob, I., \& Sowada, C. (2019). The 2017 reform of the hospital sector in Poland - The challenge of consistent design. Health Policy, 123(6), pp. 538-543. https://doi.org/10.1016/j.healthpol.2019.03.013 Ginter, P. M., Duncan, W. J., \& Swayne, L. E. (2018). The strategic management of health care organizations. USA: John Wiley \& Sons.

Kravchenko, S.O., \& Shpachuk, V.V. (2019). Directions of the State policy of healthcare reform in Ukraine. International Journal of Advanced Biotechnology and Research, Special Issue-1, pp. 580 - 586.

Lekhan, V., Rudiy, V., \& Shishkin, S. (2007). The Ukrainian health financing system and options for reform: a thorough analysis of the health care financing system in the Ukraine and suggestions for feasible changes. Copenhagen: WHO Regional Office for Europe

Lekhan, V.N., Rudiy, V.M., Shevchenko, M.V., \& Nitzan Kaluski, D., \& Richardson, E. (2015). Ukraine: Health system review. Health Systems in Transition, 17(2), pp. 1-153.

Ling, L., \& Hongqiao, F. (2017). China's healthcare system reform: Progress and prospect. International Journal of Health Planning and Management, No. 32, pp. 240-253. https://doi.org/10.1002/hpm.2424

Mikhno, I., Koval, V., \& Ternavskyi, A. (2020). Strategic management of healthcare institution development of the national medical services market. Access to Science, Business, Innovation in Digital Economy, 1(2), pp. 157-170. https://doi.org/10.46656/access.2020.1.2(7)

Muzyka, I.S. (2016). Reformation of health protection: problems, analysis, implementation directions (by example of the Carpathian region of Ukraine). Economics and the national economy management, No.2, pp. 38-43.

Nasiri, F., \& Moselhi, O. (2017). Healthcare facilities maintenance management: a literature review. Journal of Facilities Management, 15(4), pp. 1-24.

Obama, B. (2016). United States healthcare reform progress to date and next steps. JAMA, 316(5), pp. 525-532. https://doi.org/10.1001/jama.2016.9797

Paryzkyi, I.V. (2018). State Policy of Innovative Development of National Economy: Situation and Issues of Implementation. Journal of Advanced Research in Law and Economics, 9(8), 


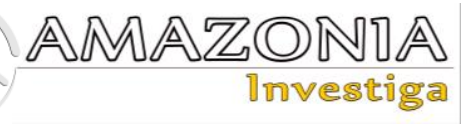

pp.

2721-2732. https://journals.aserspublishing.eu/jarle/article/v iew/4129

Pashkov, V., Udovyka, L., \& Dichko, H. (2018). International medical law and its impact on the Ukrainian health care legislation. Wiadomości Lekarskie, Vol. LXXI, No. 1, Part II, pp. 201-205.

Rechel, B., Blackburn, C.M., Spencer, N.J., \& Rechel, B. (2011). Regulatory barriers to equity in a health system in transition: a qualitative study in Bulgaria. Health Policy, 123(6), pp. 538-543. https://doi.org/10.1186/1472-696311-219

Safonov, Yu. M., \& Borshch, V. I. (2019). Strategic model of managing healthcare facilities. Global Academics, No. 3(4), pp. 15-22. Shevchuk, O., Zui, V., Kompaniiets, I., Martynovskyi, V., \& Matat, Y. (2021). Publicprivate partnerships in the healthcare sphere: legal models in Ukraine and foreign countries. Amazonia Investiga, 10(37), pp. 168-179.

https://doi.org/10.34069/AI/2021.37.01.17. https ://amazoniainvestiga.info/index.php/amazonia/a rticle/view/1535

Shevchuk, V., Chernyak V., Kovalchuk T., Pedan, M., Pankov, O. et al. (2016). The development for salvation. Kyiv: Geoprint. http://www.irbis-nbuv.gov.ua/cgibin/irbis_nbuv/cgiirbis_64.exe?C21COM=S\&I2 $1 \mathrm{DBN}=\mathrm{EC} \& \mathrm{P} 21 \mathrm{DBN}=\& \mathrm{~S} 21 \mathrm{FMT}=\mathrm{JwU} \_\mathrm{B} \& \mathrm{~S} 2$

$1 \mathrm{ALL}=\% 28 \% 3 \mathrm{C} . \% 3 \mathrm{EI} \% 3 \mathrm{D} \% 21 \mathrm{NBUV} \$ \% 3 \mathrm{C}$. $\% 3 \mathrm{E} \% 29 \% 2 \mathrm{~A} \% 28 \% 3 \mathrm{C} . \% 3 \mathrm{EU} \% 3 \mathrm{D} \% \mathrm{D} 0 \% \mathrm{~A} 39$ $\% 284 \% \mathrm{D} 0 \% \mathrm{~A} 3 \% \mathrm{D} 0 \% 9 \mathrm{~A} \% \mathrm{D} 0 \% \mathrm{~A} 0 \% 29280 \% 3$ C. $\% 3 E \% 29 \& Z 21 \mathrm{ID}=\& S 21 \mathrm{SRW}=\mathrm{TIPVID} \& \mathrm{~S} 21$ $\mathrm{SRD}=\mathrm{DOWN} \& \mathrm{~S} 21 \mathrm{STN}=1 \& \mathrm{~S} 21 \mathrm{REF}=10 \& \mathrm{~S} 21$ $\mathrm{CNR}=20$

Shohet, I.M. (2006). Key performance indicators for strategic healthcare facilities maintenance. Journal of Construction Engineering and Management, 132(4), pp. 345-352.

Tomchuk-Ponomarenko, N.V., Lozova, G.M., Pashniuk, L.O., \& Krasnopolska, T. (2021). Transformation of Public Administration of the Social and Economic Policy in Ukraine by the Example of the Healthcare Reformation. Journal of Environmental Treatment Techniques, 9(2), pp. 421-427. https://doi.org/10.47277/JETT/9(2)427

UN General Assembly (2015). Resolution adopted by the General Assembly on 25 September 2015 "Transforming our world: the 2030 Agenda for Sustainable Development". Available online. In: https://www.un.org/ga/search/view_doc.asp?sy $\mathrm{mbol}=\mathrm{A} / \mathrm{RES} / 70 / 1 \&$ Lang $=\mathrm{E}$

Vasyuk, M. (2018). Public administration bodies as subjects of services in the medical sector of Ukraine. Entrepreneurship, Economy and Law, No. 12, pp. $172-175$.

Voronenko, Yu.V, \& Goyda, N.G. (2013). Healthcare reformation: success and obstacles. Modern medical technology, No. 2, pp. 24-26. 